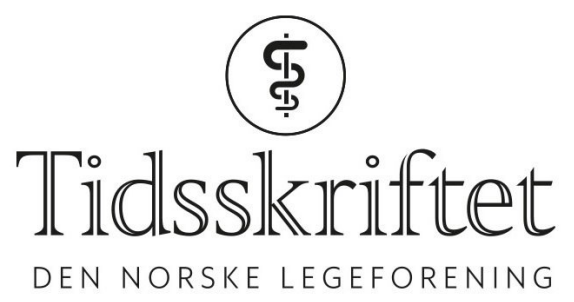

\title{
Hvor stor andel av traumepasientene bør undersøkes med CT?
}

KOMMENTAR

BJ ØRN EINAR NIELSSEN

E-post: bnielsse@gmail.com Bjørn Einar Nielssen er overlege i radiologi. Ingen oppgitt interessekonflikter.

Torben Wisborg trekker frem variasjon i bruk av CT som primærundersøkelse av skadete pasienter (1). Artikkelen i Lancet, som Wisborg viser til, sammenlignet bruk av tidlig traume-CT ved multitraume med «standardutredning» av traumepasienter (2). Ved standardutredning av multitraume ble CT også brukt på kliniske problemstillinger. I denne studien fant man at «helkropps-CT» medførte redusert tid i akutttrom og lavere kostnader sammenlignet med «standardutredning». Gjennomsnittlig stråledose var rundt $20 \mathrm{mSv}$ i begge gruppene. $46 \%$ av pasientene i «standardutrednings-gruppen» fikk gjort CTundersøkelser som utgjorde minst en «helkroppsundersøkelse». Noen av disse fikk flere kontrastinjeksjoner. Undersøkelsen konkluderte med at «in-hospital mortality» var den samme i begge gruppene, men vurderte ikke gevinsten ved å påvise annen patologi (2).

I Nasjonalt traumeregisters årsrapport for 2017 heter det om traume-CT: «Undersøkelsen har høy treffsikkerhet på identifisering av skader, men medfører stråling av pasienter og bør ikke gjøres på pasienter som klinisk er våkne uten tegn til skader» (3). CT er best for å påvise skade av nakke, rygg og bekken i akuttsituasjonen. En av tre bekkenfrakturer overses på konvensjonell røntgen. For nakkefrakturer er andelen høyere (4). Andre ikke dødelige tilstander det kan være nyttig å påvise er intrakranielle blødninger, pneumo/hemothorax, intraabdominale bløtdelsskader etc.

Teoretisk risiko for at stråling ved CT-undersøkelser ved traume skal indusere kreft må veies opp med den diagnostiske gevinsten og lave risikoen ved undersøkelsen.

Risikovurderingen har vært basert på LNT-teorien («linear no-threshold»), som angir lineær sammenheng mellom stråledose og kreftrisiko. Det finnes, det meg bekjent, ingen studier eller epidemiologiske data som har vist dette ved lave stråledoser. Mange epidemiologiske studier har ikke funnet slik sammenheng (5).

US Food and Drug Administration baserer seg på LNT-teorien. De skriver at kan være økt risiko, og nevner at risikoen ved aktuelle stråledoser er så liten at den nesten kan forsvinne i statistisk støy og usikkerhet (6). Dette skal veies opp mot risikoen for å overse alvorlig patologi. Det er ikke nødvendigvis slik at redusert CT-bruk er riktigere bruk.

Multitraumeprotokoll skal kun brukes på god indikasjon, men i traumesettingen har undersøkelsen høy diagnostisk effektivitet. En slik undersøkelse kan overflødiggjøre andre 
undersøkelser som ultralyd og gjentatte CT-undersøkelser med gjentatte

kontrastinjeksjoner, samt eksplorative inngrep.

\section{LITTERATUR:}

1. Wisborg T. Overforbruk av CT ved traumemottak? Tidsskr Nor Lægeforen 2019; 139. doi: 10.4045/tidsskr.19.0038. [PubMed][CrossRef]

2. Sierink JC, Treskes K, Edwards MJ et al. Immediate total-body CT scanning versus conventional imaging and selective CT scanning in patients with severe trauma (REACT-2): a randomised controlled trial. Lancet 2016; 388: 673-83. [PubMed][CrossRef]

3. Nasjonalt traumeregisters årsrapport 2017.

https://www.kvalitetsregistre.no/sites/default/files/40_ny_arsrapport_2017_nasjonalt_traumeregister .pdf(15.3.2019).

4. Parizel PM, van der Zijden T, Gaudino S et al. Trauma of the spine and spinal cord: imaging strategies. Eur Spine J 2010; 19: 8-17. [PubMed][CrossRef]

5. Kjellevand TO. Aftenposten 2.6.2016.

https://www.aftenposten.no/meninger/kronikk/i/x3JJV/Kronikk-Medisinsk-straling-er-ikke-farlig-likev el-Tor-Ole-Kjellevand (15.3.2019).

6. US Food and Drug Administration. What are the radiation risks from CT?

https://www.fda.gov/Radiation-emittingProducts/RadiationEmittingProductsandProcedures/Medical Imaging/MedicalX-Rays/ucm115329.htm (15.3.2019).

Publisert: 6. mai 2019. Tidsskr Nor Legeforen. DOI:10.4045/tidsskr.19.0270

(C) Tidsskrift for Den norske legeforening 2020. Lastet ned fra tidsskriftet.no 